\title{
Protokolljavaslat halálhír közlésére a sürgősségi betegellátásban
}

\author{
Dr. Máté Orsolya, Kovács Attila, Németh Ferenc, Dr. Simon Klára \\ Pécsi Tudományegyetem, Egészségtudományi Kar
}

\begin{abstract}
Absztrakt
Tekintettel arra, hogy a sürgősségi osztályra kerülő betegek mintegy 0,5-0,7\%-a hal meg, gyakorlatilag órákkal a felvétel után, így számolni kell azzal, hogy az ellátóknak gyakran kell rossz hírt közölniük, mely embert próbáló feladat. A felmérések szerint nincs kellő mértékű ismeret és tapasztalat ebben a témakörben, pedig a halálhír közlésének méltó kivitelezése döntő fontosságú a gyászfolyamat során. A kiterjesztett
\end{abstract}

hatáskörü ápoló kompetenciái közé már a rossz hírek illetve a halálhír közlése is beletartozik. A tájékoztatási kötelezettség megfelelő színvonalú kivitelezéséhez nyújt segítséget jelen, speciálisan a sürgősségi osztályra adaptált irányelv javaslat.

Kulcsszavak: halálhír, kommunikáció, protokoll, APN, sürgősségi betegellátás

\section{Proposal to a guideline for breaking bad news eg. death in the ER setting}

\begin{abstract}
Due to the fact that $0,5-0,7 \%$ of the patients admitted to the ER pass away literally hours after the admission, ER health care professionals are frequently placed in the unenviable hard situation of breaking bad news to the family. Studies shows that health care professionals haven't got the required knowledge and practice in this field, however the quality of the information sharing about the death is crucial also in the grieving process
\end{abstract}

\section{Bevezetés}

A sürgősségi ellátásnak több szempontból is sajátos az ellátási karaktere, pl. a sürgősségi betegellátásba többnyire nem tervezetten kerülnek a kritikus állapotban lévő betegek. Egyre több beteg kerül sikeresen stabilizálásra, bizonyos százalékuk azonban meghal az osztályon, mely általában felkészületlenül éri a hozzátartozókat. Az esetszámokat összehasonlítva például Dániában összes felvételre kerülő beteg vonatkozásában a sürgősségi osztályon történő halálozás például 0,51\% [1] míg Törökországban ez az arány 0,72\% [2].
Informing the family about the death is part of the APRN's scope of practice newly. Current guideline proposal aiming to help the breaking bad news to an appropriate standard, especially adapted for the ER setting.

Keywords: breaking bad news eg. death, communication, guideline, APRN, ER setting

Ezen adatok alapján kimondható, hogy egy átlagos sürgősségi osztályon, kb. napi 100 beteg esetszámmal statisztikailag adott, hogy az ellátóknak cirka minden 2. napon halálhírt kell közölnie a hozzátartozóval.

Tekintettel arra, hogy tanulmányok sora bizonyítja [3], hogy halálhír közlésének körülményei elkísérik a hozzátartozókat életük végéig, így a közlés megfelelő minőségű kivitelezése döntő fontosságú a normál gyászfolyamat megélésében. 
Egy orvos praxisa során általában több, mint 150.000 orvos-betegtalálkozás részese, ennek ellenére az orvosi kommunikáció általában nem kötelezően teljesítendő része az orvosi képzésnek [4]. Coulehan szerint a ma praktizáló orvosok nagy része, sem szervezett keretek közt, az alapoktatásban, sem pedig postgraduálisan kommunikációs tréning keretein belül nem kapott ilyen irányú felkészítést [5]. Ramirez [6]. tanulmányában leírja, hogy ha az orvosoknak biztosítható lenne a lehetőség kommunikációs készségeik fejlesztésére, mely révén magabiztosabban tudják kielégíteni betegeik információs és emocionális igényeit, az csökkenhetné az orvosok pszichés terhelését, és az őket érő napi stresszt és esetükben sokkal kisebb lenne a kiégés kockázata. A fentiekben látható, hogy még a közlő szerepét az eddigiekben kizárólag betöltő orvosok sem kapnak elég és kellően adekvát információt e nehéz és embert próbáló feladat elvégzéséhez, a jelenlegi kiterjesztett hatáskörű ápolók pedig még nagyon újak ezen a kompetencia területen.

Jelen, a nemzetközi és hazai ajánlásokra épülő irányelv célul tűzte ki, hogy megfelelő támogatást biztosítson az orvosoknak és a kiterjesztett hatáskörü ápolóknak, nehéz feladatuk, a rossz hírek közlésének megfelelő minőségü kivitelezéséhez.

A betegellátásban rossz hírnek nevezünk minden olyan hírt ami, „drasztikusan és negatívan megváltoztatja a páciens életének jövőképét" [7]. Egy másik megfogalmazásban: „minden olyan szituáció, amelynek során vagy reménytelenség érzése vagy az egyén szellemi vagy testi jóllétét érintő fenyegetés vagy eddig megszokott életvitelének megingása vagy olyan közlés, ami megfosztja az egyént az individuális döntés lehetőségétől." [8]. Rossz hír lehet egy gyógyíthatatlan betegség diagnózisának közlése a beteggel, [9] a beteg halálának közlése a hozzátartozóval, de akár egy a beteg életét véglegesen befolyásoló betegség pl. a diabetes diagnózisa. A rossz hír közlésénél, még a legjobb felkészültség esetén is sokkolják a pácienst vagy a hozzátartozót, és fontos, hogy a tájékoztató tisztában legyen azzal, hogy tájékoztatott élete végéig emlékezni fog a tájékoztatás során történtekre [10]. Buckmann [7] szerint az ellátókat a következők viselik meg rossz hírek közlésénél: másoknak szenvedést, fájdalmat okozni; az ellátó félelme a váratlan reakcióktól; az ellátó félelme, attól, hogy saját érzelmeit sem tudja kontrollálni. A külföldi szakirodalomban a halálhír közlését gyakorta egy tanulmányban említik egyéb rossz hír közléséhez segítséget nyújtó módszerekkel, mert a halálhír is tulajdonképpen egy rossz hír. Oken [11] 1961-es tanulmánya szerint az orvosok 90\%-a eltitkolta a gyógyíthatatlan betegség tényét a beteg elött. Ez az arány 1979-re megfordult, akkor már az orvosok 97\%-a közölte a pácienssel a rosszindulatú betegséget, derült ki Novack [12] vizsgálatából. A korábbi közlési attitűd Magyarországon is jellemző volt. Az ezredforduló után azonban szemléletváltás történt, amiben jelentős szerepe volt az 1997. évi CLIV. Egészségügyi Törvény megjelenésének. A Törvény deklarálja a beteg teljes körű tájékoztatását. Tekintettel a Törvényben meghatározottakra a közlés szükségessége nem lehet kérdés a továbbiakban, annál nagyobb igény van azonban a közlés módjának tökéletesítésére. Az orvos- és egészségtudományi BSc és MSc képzésekben valamint a szakképzésekben a kommunikációs képzések még mindig nem az optimális óraszámban történnek, így nem jut elég idő a rossz hír közlés korrekt, empatikus módjának az elsajátítására. Egyes szakirodalmi források szerint az ápolók, képzési szinttől függetlenül is, külföldön nagyobb szerepet kapnak a rossz hír közlésénél, mint hazánkban, szerepük szerteágazó, pl. segítséget nyújtanak az optimális közlési körülmények előkészítésében, monitorozzák a hozzátartozók érzelmi állapotát, felmérik a család pszichés és szociális körülményeit, segítséget nyújtva az orvosnak ezzel rossz hír empatikusabb közlésében. Ezen túlmenően jelen van a közlés alatt, hiszen a rossz hírek közlésekor bekövetkező beszűkült tudatállapotban a tájékoztatott rosszul interpretálhat információkat. Az ápoló jelenléte tanúként, támaszként segítséget nyújthat az ilyen természetű konfliktusok kezelésében. Tájékoztatja a hozzátartozókat beteg állapotváltozásáról, kezelésekről, egyéb ellátási lehetőségekről [14]. Ezzel szemben Magyarországon mindezidáig sem tisztázott, hogy meddig terjed az ápoló kompetenciája a beteggel való kommunikációban. Az OKJ-s ápoló képzés során pusztán 2 tanévben tanulnak kommunikációt, heti 1,5, majd heti 0,5 órában. Ebből speciális kommunikációról is összesen csak 18 órát. (37/2013 EMMI rendelet kerettanterve szerint). A magyarországi szakirodalmi adatok áttanulmányozása során nem sikerült olyan jogszabályt, rendeletet, esetleg kompetencia leírást találnunk, amely törvényileg, ill. szakmapolitikailag elöírta volna, vagy akár ajánlást fogalmazott volna meg arra vonatkozólag, hogy milyen szerepet tölthet be az ápoló a rossz hír közlésekor. Közölhet-e önállóan rossz hírt, 
ha igen, milyen természetüt (pl. rossz prognózisú diagnózist, halálhírt is vagy állapotrosszabbodással kapcsolatos információkat, vagy csak jelen lehet e rossz hírek közlésekor). Az ápoló jelenlétével a szülő biztosítékot nyerhet a tájékoztatás folytonosságáról, tekintettel arra, hogy az ápolók szakirodalmi adatok szerint jelentősen több időt töltenek a betegek mellett, mint orvosaik, így könnyebben elérhetők a szülők számára.

\section{Halálhír közlésére szolgáló protokolljavaslat a sürgősségi betegellátásban}

Jelen protokolljavaslat a Magyar Nemzeti Erőforrás Minisztérium 2010-es szakmai irányelve alapján készült [14], ami a pszichológiai feladatokat veszi sorra szüléshez társuló veszteségek során, kiegészítve a külföldi szakirodalmakból kiemelt javaslatokkal [7], [15-21], amik kifejezetten a rossz hír közlésével és a halálhírrel foglalkoznak. A protokoll a sürgősségi betegellátásban dolgozó orvosoknak, mentőtiszteknek és kiterjesztett hatáskörű ápolóknak készült, akik sürgősségi osztályon, intenzív terápiás osztályon illetve az akut betegellátás valamely más területén dolgoznak és célja a halálhír közlésének minél inkább szakértő és empatikus módon történő kivitelezése, csökkentve ezáltal a hozzátartozók gyászreakcióját és fájdalmát, csökkentve az ellátóra háruló lelki megterhelést, így a kiégés veszélyét is.

\section{Előkészítés}

a) Jegyezzük meg az elhunyt teljes nevét.

b) Készüljünk fel a halál körülményeiről és az elhunyt anamnéziséről.

c) Biztosítsunk időt magunknak a halálhír közlésére. Intézzük úgy, hogy ne tudjanak minket zavarni, kapcsoljuk ki a mobiltelefonunkat/ csipogónkat.

d) Cseréljük le a véres, vagy egyéb váladékkal szenynyezett ruhánkat.

e) Szervezzünk magunk mellé egy tapasztalt kollégát az ellátószemélyzetből

\subsection{Kapcsolatfelvétel}

a) Keressük meg a hozzátartozókat.

b) Mutatkozzunk be, és tájékoztassuk a hozzátartozókat a szerepünkről az ellátásban.

c) Ha a hozzátartozó egyedül van, kérjük meg, hogy hívjon be más családtagot is a kórházba. d) Tisztázzuk, hogy a jelenlévők milyen rokoni kapcsolatban vannak az elhunyttal.

e) Keressünk egy csendes, privát szobát, lehetőség szerint nem a közvetlen klinikai környezetben.

f) Próbáljuk a tájékoztatandók körét 2-3 före limitálni, foglaljanak helyet a szobában, vegyük fel egyikükkel a szemkontaktust.

g) Készítsük fel a hozzátartozókat, hogy most rossz híreket fognak kapni. (pl. „attól tartok, rossz hírt kell közölnöm”, illetve „sajnos a dolgok nem úgy alakultak, ahogy szerettük volna”)

h) Készítsünk elő papírzsebkendőt és egy üveg vizet a szobába.

i) Ha a beteg halálakor nincs jelen hozzátartozó, telefonon kell értesítenünk a hozzátartozót, de tartózkodjunk a telefonon történő halálhír közlésétől. Amennyiben lehetséges, kérjük meg, hogy fáradjon be a kórházba, mert váratlan állapotroszszabbodás lépett fel a betegnél. Ha ez a távolság, vagy bármi más miatt kivitelezhetetlen, akkor telefonon keresztül kell közölnünk a halálhírt.

j) Telefonon történő tájékoztatáskor jegyezzük fel, hogy pontosan kivel beszélünk, és milyen rokoni kapcsolatban van az elhunyttal. Ilyen esetben is előtte kérjük meg a hozzátartozót, hogy üljön le, hívjon maga mellé valakit, aki lelkileg tudja támogatni.

k) Ha a beteg még életben van: tájékoztassuk a hozzátartozókat, hogy a beteg kritikus állapotban van, ellátása folyamatban. Amennyiben a szituáció engedi, engedjük meg a hozzátartozóknak, hogy egy rövid látogatást tegyenek a betegnél. Ezután beszéljünk velük a várható kimenetelekröl, készítsük fel őket, hogy rossz hírt is kaphatnak. Ajánljuk fel, hogy hívunk papot, vagy egyéb vallási segítőt, hogy imádkozzon a hozzátartozójukért.

\subsection{Tájékoztatás}

a) Tájékoztassuk a hozzátartozókat, hogy a beteg meghalt.

b) Nyilvánítsunk részvétet, mondjuk, hogy „nagyon sajnáljuk” vagy „nagyon bíztam benne, hogy másként végződik”, nyugtassuk meg, hogy az ellátószemélyzet keményen küzdött a betegért.

c) Kerüljük a félreérthető kifejezéseket, mint például, hogy „elment” vagy „nincs többé” és az olyan frázisokat, mint például „az idő minden sebet begyógyít". 
d) Mérjük fel a hozzátartozó igényeit arról, hogy mit szeretne tudni a halál körülményeiről.

e) Ha a hozzátartozó igényli, tájékoztassuk, hogy mi vezethetett a beteg halálához, hogyan zajlott az ellátás, etc.

f) Kerüljük az idegen/latin vagy szakkifejezéseket, fogalmazzunk érthetően.

g) Az információátadás módja fejezzen ki empátiát, együttérzést, ne kapkodjunk, ne akarjunk minél előbb szabadulni ebből a feltehetően kényelmetlen szituációból.

\begin{tabular}{|c|c|}
\hline JAVASLATOK & ELKERÜLENDŐK \\
\hline $\begin{array}{l}\text { Használjunk egyszerủ és érthető } \\
\text { szavakat. }\end{array}$ & $\begin{array}{l}\text { NE használjunk orvosi } \\
\text { kifejezéseket. }\end{array}$ \\
\hline $\begin{array}{l}\text { Könnyebb, ha megfogalmazzuk } \\
\text { érzéseinket. }\end{array}$ & $\begin{array}{l}\text { NE meneküljünk el a kérdések } \\
\text { elöl. }\end{array}$ \\
\hline $\begin{array}{l}\text { Figyeljünk a hozzátartozók } \\
\text { igényeire, adjunk teret a } \\
\text { kérdéseknek és az érzelmek } \\
\text { megélésének }\end{array}$ & $\begin{array}{l}\text { NE vitatkozzunk a } \\
\text { hozzátartozókkal, és ne } \\
\text { erőltessük rájuk a saját } \\
\text { akaratunkat. }\end{array}$ \\
\hline „Nagyon sajnálom." & „Ez volt Isten akarata" \\
\hline $\begin{array}{l}\text { "Nagyon bíztam benne, hogy } \\
\text { máshogy végződik." }\end{array}$ & "Majd túllesz rajta" \\
\hline "Nem tudom, mit mondhatnék." & \begin{tabular}{|l|} 
"Rosszabbul is végződhetett \\
volna."
\end{tabular} \\
\hline „Engem is mélyen érint." & „Az a legjobb, hogy így történt.” \\
\hline $\begin{array}{l}\text { "Nagyon szomorú vagyok a } \\
\text { történtek miatt." }\end{array}$ & "„Az idő a legjobb gyógyszer.” \\
\hline $\begin{array}{l}\text { "Van kérdésük bármivel } \\
\text { kapcsolatban?" }\end{array}$ & Rosszabb esetek felemlegetése \\
\hline $\begin{array}{l}\text { "Ha gondolják, később is tudunk } \\
\text { beszélni." }\end{array}$ & $\begin{array}{l}\text { A hozzátartozók érzéseinek } \\
\text { minősítése }\end{array}$ \\
\hline
\end{tabular}

\subsection{Reakciók}

a) Figyeljük a hozzátartozók reakcióira.

b) Hallgassuk meg őket, támogassuk non-verbálisan is a gyászreakciójukat, például érintsük meg a kezüket, vállukat, ha ez a tájékoztató egyéni megítélése szerint helyénvalónak tünik adott helyzetben.

c) Hagyjunk pár percet a hozzátartozóknak, hogy feldolgozzák a kapott információt.

d) Ha a beteg eszméletlen volt, vagy komatózus állapotban halt meg, beszéljünk arról, hogy a halál beálltakor nem szenvedett, nem voltak fájdalmai. e) Amennyiben a hozzátartozók agresszíven viselkednének, gondoskodjunk róla, hogy a biztonsági személyzet a közelben legyen.

f) Amennyiben a hozzátartozó hangos, vigasztalhatatlan sírásba kezd, kb. 2-4 perc után, próbáljuk visszaterelni a realitásokhoz, például a zárójelentés aláíratásával vagy egyéb adminisztratív feladatok elláttatásával, hogy időlegesen kizökkentsük ebből a lelkiállapotból.

g) Ajánljuk fel, hogy hívunk az elhunythoz lelkészt vagy egyéb vallási segítőt, ajánljuk fel pszichológus vagy családsegítő, gyászterapeuta bevonását.

h) Amennyiben van tudomásunk/brosúránk megfelelő önsegítő csoportról vagy civil szervezetről, ami hathatós segítséget nyújthat, ajánljuk fel a hozzátartozónak.

\section{4 Összegzés}

a) Tájékoztassuk a hozzátartozókat, hogy a holttest a patológiai osztályra fog kerülni, mikor és hogyan fogják megkapni a zárójelentést/halotti anyakönyvi kivonatot.

b) Tájékoztassuk a hozzátartozókat arról, ha igazságügyi boncolás elrendelése szükséges.

c) Adjuk át az elhunyt személyes dolgait/értékeit.

d) Ajánljuk fel, hogy megtekinthessék a holttestet, föleg ha nem voltak jelen a kórházban az ellátás alatt.

e) Takarjuk be a holttestet, tisztítsuk meg a vértől, és egyéb testváladékoktól, illetve defibrillátor zselétől.

f) Gondoskodjunk róla, hogy a holttest mellett mindig legyen valaki jelen az ellátóteamből, amíg a hozzátartozók jelen vannak.

\section{Összefoglalás}

Jelen összefoglaló hathatós és gyakorlatias tanácsokat próbál adni az ellátóteam azon tagjai részére, akiknek kompetenciájában a rossz hír, illetve halálhír közlése szerepel. Ez a lelkileg megterhelő feladat jelenleg már nem kizárólag az orvosi kompetenciakör része, tekintettel arra, hogy a kiterjesztett hatáskörű ápolói szerep képzési és kimeneti kompetenciái (18/2016. (VIII. 5.) EMMI rendelet) [22] között szerepel a rossz hírek közlésének kiterjesztett ápolókra való átruházásának lehetősége.

Magyarországon jelenleg kizárólag a Nemzeti Erőforrás Minisztérium szakmai irányelvére lehet 
támaszkodni, mely a perinatális veszteségek közlésére és a páciens közvetlen pszichés vezetésére irányul. Jelen összefoglalás magában foglalja ezen irányelv és a külföldi rosszhír és halálhír közlési szakirodalmak alapján látótérbe került ismereteket, annak érdekében, hogy ezt az embert próbáló szituációt elviselhetőbbé tegye a tájékoztatott és nem utolsó sorban a tájékoztató részére.

\section{Irodalomjegyzék}

1. Søvsø MB, Hermansen SB, Færk E, et al. Diagnosis and mortality of emergency department patients in the North Denmark region. BMC Health Services Research. $2018 \mathrm{Jul} ; 18(1): 548$.

2. Oray NC, Oray D, Aksay E, Atilla R, Bayram B. The impact of a heat wave on mortality in the emergency department. Medicine (Baltimore). 2018;97(52):e13815.

3. Harrahill M. Giving bad news gracefully. J Emerg Nurs. 2005;31(3):312-314.

4. Müller Michael,Der star ke Auftritt. Eichborn, 2000. München

5. Coulehan, J L; Nardini, Patient simulation and teamteaching in a medical interviewing course Patient simulation and team-teaching in a medical interviewing course, Academic medicine, 1982. 57: 7-19.

6. Ramirez AJ Graham J, Richards MA, Cull A, Gregory WM Mental health of hospital consultans: the effect of stress and satisfaction at work. Lancet 1996.347: 724-28.

7. Buckmann Robert, How to break bad news: A guide for health care professionals. Baltimore,1992 The J. Hopkins University Press; 15.

8. Robert Bor, Riva Miller, Eleanor Goldman \& Isobel Scher, The meaning of bad news in HIV disease: Counselling about dreaded issues revisited, Counselling Psychology Quarterly, 1993, 6:1, 69-80,

9. Verzar Z; Kövér E, Doczi T, Koppan M, Bodis J: Successful treatment of FIGO stage IV gestational choriocarcinoma osccuring 2 months after delivery .Eur.Journal of Obstetric Gynecology and Reproductive Biology 140:2pp 275-276

10. Donovan, K. Communicating bad news, WHO Division of Mental Health 1993, http://whqlibdoc. who.int/hq/1993/WHO_MNH_PSF_93.2.B.pdf (letöltve 20014.02.)

11. Oken, Donald (1961): What to Tell Cancer Patients, A Study of Medical Attitudes JAMA; 1961, 175:1120-28

12. Novack Dennis H. H. Shamoon, H. Duffy, (1979): Changes in Physicians' Attitudes Toward Telling the Cancer Patient 1979, 241: 9-14.

13. Crawford D et al. Educating children's nurses for communicating bad news. Nursing Ohildren And Young People, 2013, 25-33.

14. Szülészeti és Nőgyógyászati Szakmai Kollégium és az Országos Gyermekegészségügyi Intézet A Nemzeti Erőforrás Minisztérium szakmai irányelve a pszichológiai feladatokról szüléshez társuló veszteségek során, 2010 https://mave.hu/uploads/file/Szul_szuleshez\%20 tarsulo\%20veszteseg_iranyelv.pdf. letöltve 2020.08.

15. Girgis A, Sanson-Fisher RW. Breaking bad news: consensus guidelines for medical practitioners. J Clin Oncol. 1995, 13:2449-56.

16. Ptacek JT, Eberhardt TL (1996): Breaking bad news. A review of the literature. JAMA. 1996, 276:496-502.

17. Pueschel SM, Murphy A. Assessment of counseling practices at the birth of a child with Down's syndrome., Am J Ment Defic. 1977, 81:325-30

18. Rosenzweig M. Q. Breaking bad news: A guide for effective and empathetic communication, Nurse Practioner 2012 37(2): 1-4

19. Sadananda B. Naik Death in the hospital: Breaking the bad news to the bereaved family, Indian Journal of Critical Care Medicine 2013, 17(3): 178-181

20. Corey V. R., Gwyn P. Experiences of Nurse Practioners in Communicating Bad News to Cancer Patient, Journal of the Advanced Practitioner in Oncology, 2016, 7(5): 485-494

21. Pereira C., Marchetti M., Lemonica L., Moreira de Barros G. The P-A-C-I-E-N-T-E Protocol: An instrument for breaking bad news adapted to the Brazilian medical reality, Rev Assoc Med BRas 2017;63(1): 43-49

22. 18/2016. (VIII. 5.) EMMI rendelet a felsőoktatási szakképzések, az alap- és mesterképzések képzési és kimeneti követelményeiről, valamint a tanári felkészítés közös követelményeiről és az egyes tanárszakok képzési és kimeneti követelményeiről szóló 8/2013. (I. 30.) EMMI rendelet módosításáról, https://net.jogtar.hu/jogszabaly?docid=A1600018. EMM\&txtreferer=00000001.TXT, letöltve, 202008. 